MAKING USE OF

BIOLOGY 
Other titles in this series

Making Use of Mathematics for GCSE, G. Buckwell and A. Ball Making Use of Physics for GCSE, R. Kibble 


\section{MAKING USE OF \\ BIOLOGY}

Pauline Alderson

and

Martin Rowland

Second Edition 
All rights reserved. No reproduction, copy or transmission of this publication may be made without written permission.

No paragraph of this publication may be reproduced, copied or transmitted save with written permission or in accordance with the provisions of the Copyright, Designs and Patents Act 1988, or under the terms of any licence permitting limited copying issued by the Copyright Licensing Agency, 90 Tottenham Court Road, London WIP 9HE.

Any person who does any unauthorised act in relation to this publication may be liable to criminal prosecution and civil claims for damages.

First edition 1989

Reprinted 1991 (twice), 1993

Second edition 1995

Published by

MACMILLAN PRESS LTD

Houndmills, Basingstoke, Hampshire RG21 2XS

and London

Companies and representatives

throughout the world

ISBN 978-0-333-62093-9

ISBN 978-1-349-13563-9 (eBook)

DOI 10.1007/978-1-349-13563-9

A catalogue record for this book is available

from the British Library

$\begin{array}{llllllllll}10 & 9 & 8 & 7 & 6 & 5 & 4 & 3 & 2 & 1\end{array}$

04030201009998979695 


\section{CONTENTS}

Acknowledgements

vii

Experiments

ix

Introduction for teachers

xi

Introduction for students

xiii

PART 1: ECONOMIC AND ENVIRONMENTAL BIOLOGY 1

Unit 1 VARIETY OF LIVING THINGS

Unit 2 MICROORGANISMS $\quad 17$

Unit 3 GROWTH IN MICROORGANISMS 33

Unit 4 ENZYMES 43

Unit 5 RESPIRATION $\quad 55$

Unit $6 \quad$ FERMENTATION $\quad 67$

Unit 7 NUTRITION IN MICROORGANISMS

Unit $8 \quad$ NUTRITION IN FLOWERING PLANTS 99

$\begin{array}{lll}\text { Unit } 9 & \text { FLOWERING PLANTS } & 117\end{array}$

$\begin{array}{lll}\text { Unit } 10 & \text { RECYCLING } & 129\end{array}$

Unit 11 PLANT CROPS 137

Unit 12 CROPS AS ECOSYSTEMS 149

Unit 13 HUMAN EFFECTS ON THE ENVIRONMENT 161

PART 2: HUMAN AND SOCIAL BIOLOGY 173

$\begin{array}{lll}\text { Unit } 14 & \text { HUMAN CELLS } & 175\end{array}$

$\begin{array}{lll}\text { Unit } 15 & \text { FOOD } & 181\end{array}$

Unit 16 EATING AND DIET 195

Unit 17 MOVEMENT, SUPPORT AND EXERCISE 211

Unit 18 AIR SUPPLY 223

Unit 19 HEART AND CIRCULATION 235

Unit 20 TEMPERATURE CONTROL AND HOMEOSTASIS 249

Unit 21 NERVOUS AND HORMONAL CONTROL; DRUGS 261

Unit 22 FERTILISATION AND FAMILY PLANNING 271

$\begin{array}{lll}\text { Unit } 23 & \text { PREGNANCY } & 287\end{array}$

Unit 24 BIRTH TO OLD AGE 301

Unit 25 GENETICS, CELL DIVISION, DNA AND GENETIC ENGINEERING 313

Unit 26 INHERITANCE, VARIATION AND NATURAL SELECTION $\quad 335$

Unit 27 HEALTH AND POPULATION DYNAMICS 349 
Appendix A: Background in mathematics and other sciences

Appendix C: How to draw; how to compare biological specimens; how to answer examination questions; how to revise

Answers 


\section{ACKNOWLEDGEMENTS}

The authors and publisher wish to acknowledge the following photograph sources:

Bernard Alfieri p. 151 (top right);

Heather Angel pp. 100, 139 (left), 152, 154 (top and bottom);

Barnaby's Picture Library pp. 59, 69, 77, 278 (b);

Camera Press pp. 252;

J. Allan Cash p. 217;

Courtaulds p. 26;

Family Planning Association p. 278 (a and c);

Glaxo Holding plc p. 91;

Richard and Sally Greenhill pp. 228, 343;

Health Education Council p. 294;

John Innes Institute pp. 140 (photo C. Hussey), 320;

National Dairy Council p. 75;

Pepperfoto p. 4;

RHM Research p. 93;

Science Photo Library pp. 18 (photo Dr Jeremy Burgess), 21 (photo Eric Grave), 23, 102, 103 (top and bottom), 124 (photo Dr Jeremy Burgess), 151 (top left), 176, 177, 178, 187 (photo Dr Howells), 242, 316, 331;

Topham Picture Library p. 165;

Turberville Smith and Son p. 220;

R. Upptograffe p. 83.

The publishers have made every effort to trace all the copyright holders, but if they have inadvertently overlooked any, they will be pleased to make the necessary arrangements at the first opportunity. 


\section{EXPERIMENTS}

Part 1

Experiment 1.1 To investigate the distribution of one plant species using quadrats at regular intervals along a belt transect

Experiment 2.1 To inoculate an agar medium with Rhizopus and measure the growth of the colony

Experiment 3.1 To find the relative numbers of milk-souring microorganisms (lactic-acid bacteria) in samples of milk using the resazurin test

Experiment 4.1 To test the hypothesis that catalase (in yeast) breaks down hydrogen peroxide

Experiment 4.2 To test the hypothesis that catalase is sensitive to temperature and to $\mathrm{pH}$

Experiment 5.1 To test the hypothesis that in respiration in yeast oxygen is used and carbon dioxide is produced

Experiment 5.2 To test the hypothesis that yeast cells produce heat during respiration

Experiment 5.3 To test the hypothesis that temperature affects the rising of a flour-yeast dough

Experiment 6.1 To show fermentation by yeast with the use of an airlock

Experiment 6.2 To make yoghurt

Experiment 7.1 To test the hypothesis that fungi secrete enzymes on to their food

Experiment 7.2 To investigate the influence of temperature on the rate of decomposition of fruit

Experiment 8.1 To investigate the structure of an Elodea leaf with a light microscope

Experiment 8.2 To test the hypothesis that plants need light to produce starch

108

Experiment 8.3 To test the hypothesis that a photosynthesising green leaf takes up carbon dioxide

Experiment 8.4 To test the hypothesis that a submerged water plant gives off oxygen

Experiment 8.5 To investigate the effect of organic and inorganic fertilisers on plant growth

Experiment 9.1 To investigate the presence of root hairs using a light microscope

Experiment 9.2 To investigate water transport in a leaf stalk or stem of a plant 
Experiment 10.1 To investigate the presence of microorganisms in a sample of filtered soil water

\section{Part 2}

Experiment 15.1 To test for starch and reducing sugar

190

Experiment 15.2 To test foods for starch and reducing sugar

192

Experiment 16.1 To measure the energy content of food

207

Experiment 18.1 To test the hypothesis that exercise affects the rate of human breathing

Experiment 19.1 To test the hypothesis that exercise affects the pulse rate 


\section{INTRODUCTION FOR TEACHERS}

This book emphasises 'social, economic, technological, ethical and cultural influences [on] and limitations [of]' the study and practice of Biology, as specified by the National Curriculum. It also covers the University of London Examinations and Assessment Council's 1995 Science: Biology B (1028) Syllabus. The Syllabus is available for any age; many schools have adopted it as a mainstream course because of its intrinsic interest. The reason there is no separate Human Biology Syllabus is that it could differ only slightly from the one covered in this book.

At least a week can be allowed for each Unit if the course is taught in a year, two weeks if it is taught in two years. Unit 6 on 'Fermentation' and Unit 25 on 'Genetics, Cell Division, DNA and Genetic Engineering' may need twice as long as most Units.

Part 1 deals with 'Economic and Environmental Biology', Part 2 with 'Human and Social Biology'. Either Part can be taught first. Students who have done no Biology before might find it easier to begin with Part 2, where the early Units cover some basic subject-matter and have experiments that are easier than most. Students coming to this Syllabus with a basic Biology background in Science might find the early Units in Part 1, where the subject-matter is unfamiliar and up to date, more interesting.

No attempt has been made to put an equal amount of practical work at the end of each Unit. The Experiments come at the ends of the Units to which they are relevant. Whereas Unit 8 has five Experiments, a number of Units have none. They may be undertaken in any order except where a 'Note to teachers' says otherwise.

You should read not only Appendix D on 'Practical Work' but also the guidance on scientific investigations given to students in Appendix B, as well, of course, as the Syllabus.

At the end of each Unit there are at least three questions of varying difficulty. Because students cannot have too much practice in answering suitable questions, it is desirable to supplement those in this book with past examination papers or specialist books of questions.

This book uses the Institute of Biology's recommendations on biological nomenclature, units and symbols for secondary education. It uses billion to mean a thousand million $(1000000000)$. For the sake of clarity it hyphenates compound adjectives including chemical compounds when they are used as compound adjectives.

Nothing in this book requires students or teachers to kill animals. Animals brought into the classroom for study should be returned unharmed to their habitats. 


\section{INTRODUCTION FOR STUDENTS}

This book tells you how yoghurt, beer and wine are made. It tells you about biological washing powders, contraception, test-tube babies, heart attacks, AIDS, drugs and new forms of food. It describes how criminals can be identified from a piece of skin, a hair root, a drop of blood or (in rape cases) a drop of semen; how smoking and drinking affect health; how we can find out if our children will be born with handicaps or disorders; how tiny organisms can be used to make things for us; how ladybirds can be used to eat the pests on crops, with the result that the pests need not be killed by chemicals that end up in our food.

It is unlike most biology textbooks because it is largely about humans and real life. Remember that what goes on in real life changes all the time. Cut out any stories you see in newspapers about new food or new methods of food production, new drugs, new methods of contraception, new dangers from pollution, advances in genetic engineering or anything else that involves something biological.

All the Units in this book have at least three questions at the end: the pages on which there are questions are flagged, which makes it easy to find them. The questions are all of the kind you will get in your GCSE examination. At the end of each Unit, the easy questions usually come first and the difficult ones last. There are answers at the end of the book but you will get greater benefit if you do not look at them until you have decided on your own answers.

There is practical work at the end of many of the Units. The practical work includes experiments from ULEAC's 1995 Science: Biology B Syllabus. Passages that affect safety are included in shaded boxes.

Appendix A tells you the bits of mathematics, physics and chemistry you need to know. Appendix $\mathrm{C}$ tells you how to draw and compare biological specimens, how to answer examination questions and how to revise. 